\title{
48. Further Evidences as to the Chronological Deter- mination of so-called Rhaeto-Liassic Floras with a Description of Minetrigonia, a new subgenus of Trigonia.*
}

\author{
By Teiichi Kobayashi and Masaru Katayama. \\ (Comm. by T. KATo, M.I.A., May 12, 1938.)
}

From the palaeobotanical stand-point Oishi ${ }^{11}$ has determined the Japanese equivalents of the Lepidopteris and Thaumatopteris zones of East Greenland in Nariwa area, Prov. Bitchu. However, whether the equivalents of these floras found in places so widely apart imply the synchronous or heterochronous parallels, is a question which evidently requires a cautious examination. After Akagi $^{2)}$ and Saeki ${ }^{3)}$ had declared the stratigraphic relation of the Pseudomonotis (Entomonotis) ochotica beds above the so-called Rhaetic plant beds in Nariwa area, Oishi" denied this status because of the presence of faults in some magnitude between the fossil beds. Then, the base of the Upper Triassic Nariwa series was not determined, and accordingly the reversing of the whole Nariwa series by the folding was not impossible. The solution of this moot question calls for an exact stratigraphic investigation in the region. Such an investigation has recently been carried out by the senior author jointly with students. ${ }^{5}$ ) As reported in his previous paper, ${ }^{6}$ the new observations, insofar as the relation of the fossil beds is concerned, agree with those of Akagi and Saeki. The reversing cannot be upheld any more, because the basal unconformity of the series was clearly manifested at this time. Furthermore, the geological age of ochotica which can stand as a Noric indicator in the Pacific Province, is precisely discussed in that paper. In consequence it is decided that the Nariwa flora of the Rhaetic aspect which was found in the strata below the ochotica beds is by no means younger than the Noric.

The geologic structure of the Nariwa area is, however, rather

* The expense of authors' researches in 1935-37 was defrayed by a grant placed at the disporsal of the senior author from the Japan Society for the Promotion of Scientific Research to which the authors wish to express here their sincere thanks. They are also indebted to Professor $T$. Kato for the reading of this paper in the Academy.

1) S. Oishi (1938), The Japanese Equivalents of the Lepidopteris and Thaumatopteris Zones of East Greenland, Proc. 14 (1938), 77.

2) K. Akagi (1928), On the Triassic Formation of Nariwa, Bitchu, (Proc. 3rd PanPacific Sci. Congr. Tokyo, 1926, vol. 2.)

3) S. Saeki (1930), Stratigraphic Bearing of Plant Fosslis, (Tôkyô-Gakugei Zasshi vol. 46.)

4) S. Oishi (1930), On the Upper Triassic Formation in Nariwa District, Bitchu, (Jour. Geol. Soc. Tokyo, vol. 28.)

5) T. Kobayashi, Y. Horikoshi and Middle Class of Geol. Inst. Imp. Univ. Tokyo, (1937), The Geological History of Kibi Plateau, (Japan. Jour. Geol. Geogr. vol. 44.)

6) T. Kobayashi (1938), On the Noric Age of the Nariwa Flora of the RhaetoLiassic Aspect, (Japan. Jour. Geol. Geogr. vol. 14.) 
complicated ${ }^{11}$ and minor faults are found in many sections as pointed out by Oishi. Therefore further proof in this respect which is obtained from a less disturbed area is desirable. The Miné series containing the similar floras in different horizons reveals a simple geologic structure. Lately Carnic Edentula ozawai ${ }^{2}$ and still later Minetrigonia hegiensis and a few other shells ${ }^{3}$ were discovered at several localities near Shirogahara which are located in this general district. The find attracted the attention of the senior author to the possibility that more evidences might be available from the areal stratigraphy which has been undertaken by the joint authors, especially by the junior author, in the last few years, and the stratigraphic succession of the Mine series ${ }^{4)}$ was determined as shown in the table :-

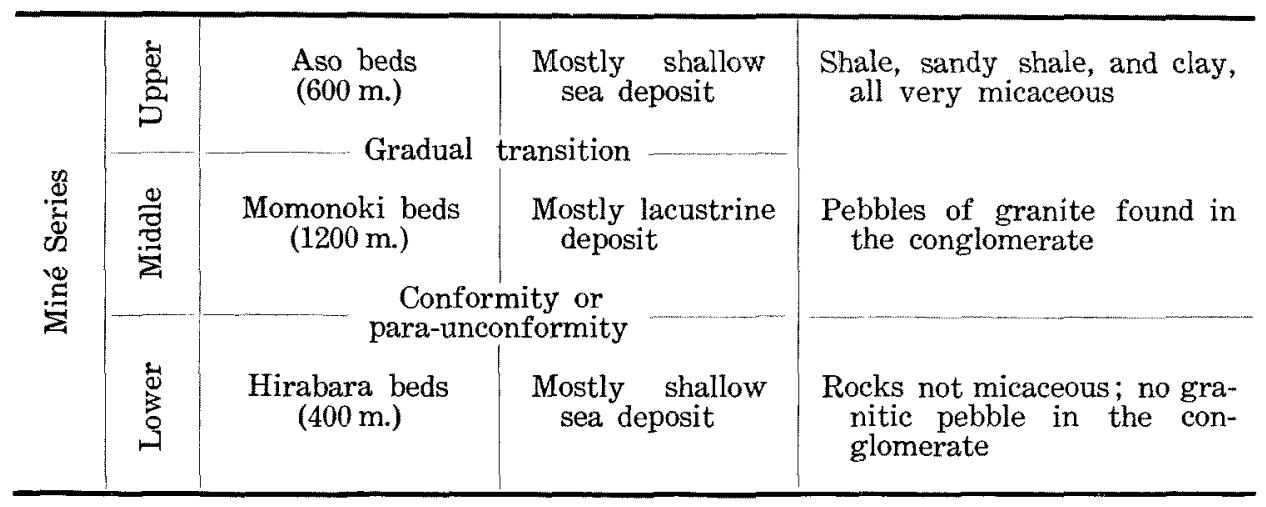

On the eastern side the Miné series unconformably overlies the Upper Palaeozoic Chichibu series of the Akiyoshi limestone plateau with the limestone conglomerate at its base. It is generally monoclinal except for the western wing where two gentle synclines appear, and its western boundary is marked by a fault along which it is in contact with the phyllitic rocks of Toyogatake. The Hirabara and Momonoki beds approximately correspond to the lower division and the Aso to the upper one of the Miné series determined by the senior author in 1926.5) As a result of recent research a number of fossil localities yielding marine and brackish shells were discovered in various horizons of the Aso and Hirabara beds and the contained faunas are so rich that it will be some years before their descriptions are complete. Among them Halobia charlyana, Edentula ozawai, Oxytoma zitteli, Minetrigonia hegiensis, Lima naumanni lata and "Pleurophorus" sp. aff. P. perlongus are significant elements of the Hirabara fauna. Pecten suzukii, Lima naumanni lata and Pseudomonotis sp. occur in the Aso beds.

1) T. Kobayashi, Outline of the Decken-Structure of the Kibi Platean in the Inner Side of Western Japan, Proc. 14 (1938), 71.

2) T. Kobayashi (1935), Einige Neue Triadische Bivalven aus Innenzone Südwest Japan, (Japan. Jour. Geol. Geogr. vol. 12.)

3) T. Kobayashi and M. Katayama (1936), “Trigonia" from the Miné Series, (Jour. Geor. Soc. Japan, vol. 43.)

4) Precise stratigraphic accounts of the Mine area will be published by the senior author through Jour. Geol. Soc. Japan in the near future.

5) T. Kobayashi (1926), Note on the Mesozoic Formations in Prov. Nagato, Chugoku, Japan, (Jour. Geol. Soc. Tokyo, vol. 33.) 
Some years ago the senior author ${ }^{1)}$ has distinguished the Halobia, Oxytoma, Myoconcha, Pecten and Pseudomonotis ochotica beds in the Carno-Noric formation in the Sakawa basin, province Tosa. As the Halobia bed contains Paratracyceras aff. hofmanni, Halobia charlyana, $H$. moluccana, $H$. talauana, Spiriferina aff. sublilangensis and others, its age can be decided at the Carnic. H. charlyana, and Lima naumanni lata are common between this Halobia bed and the Hirabara beds; Oxytoma zitteli and Minetrigonia hegiensis are common between the Oxytoma and Hirabara beds.

As the Pecten bed containing Pecten suzukii, Oxytoma zitteli and Pecten fujimotoi, is located between the Halobia and Pseudomonotis ochotica beds in the Shimoyama section in the Sakawa basin, it may be Carno-Noric or Lower Noric. The first species occurs in the Aso beds, the second in the Aso, Hirabara, Oxytoma and Myoconcha beds, and the third in a red micaceous sandstone at Kamosho, ${ }^{2)}$ where Pseudomonotis ochotica has been discovered. The last mentioned locality is at a distance of about 15 kilometers from the fossil localities of the Aso beds. In the lithic aspect this sandstone can hardly be distinguished from the fossiliferous sandstone of the Aso beds. Therefore the authors lead to the contention that the Aso is either the Noric or Carno-Noric, but its Rhaetic age can hardly be possible. The inclusion of Lima naumanni lata and Pseudomonotis sp. in the Aso fauna is a further evidence supporting this chronological determination.

During his study in the geology of the Akiyoshi limestone plateau Ozawa $^{3)}$ discovered Cycadocarpidium swabii at Ojigase which horizon is determined to be within the basal part of the Hirabara beds. Since then the senior author ${ }^{4}$ has obtain a rich collection of flora in the Momonoki beds at Kusaigawa and another in the Aso beds at Michiichi. His collection in addition to Oishi's own collection was studied by Oishi ${ }^{53}$ who distinguished the following plants:

a) Dictyophyllum japonicum Yokoyama, Nilssonia inouyei Yokoyama and Podozamites lanceolatus (L. and H.) from the Aso beds at Michiichi.

b) Neocalamites carrerei (Zeiller), Cladophlebis haiburnensis (L. and H.), C. nebbensis (Brongn.), Taeniopteris minensis Oishi, Ginkgoites digitata (Brongn.) var. huttoni Seward, Stenorachis elegans Oishi, Pityophyllum longifolium (Nathorst), Podozamites lanceolatus (L. and H.) P. schenki Heer, and Cycadocarpidium swabii Nathorst from the Momonoki beds at Kusaigawa and Momonoki.

From the floral assemblage Oishi concluded in 1932 that " there is little doubt that the flora of the Mine formation corresponds as a whole to that of the Rhaetic of the world." Ozawa (1925) and the senior

1) T. Kobayashi (1931), On the Triassic Formation and two "Klippen" of Palaeozoic Rocks in Sakawa Basin, (Jour. Geol. Soc. Tokyo, vol. 38.)

2) T. Kobayashi (1935), Op. cit. (Japan. Jour. Geol. Geogr. vol. 12.)

3) Y. Ozawa (1925), Palaeontological and Stratigraphical Studies on the PermoCarboniferous Limestone of Nagato, Pt. 2, Palaeontology, (Jour. Coll. Sci. Imp. Univ. Tokyo, vol. 45, Art. 6.)

4) T. Kobayashi (1926), Op. cit. (Jour. Geol. Soc. Tokyo, vol. 33.)

5) S. Oishi (1932), Rhaetic Plants from Province Nagato, (Yamaguchi Prefecture) Japan, (Jour. Fac. Sci. Hokkaido Imp. Univ. Ser. 4, vol. 2, No. 1.) 
author (1926) agreed with Oishi in that the Mine flora is intimately related to the Rhaetic flora in other parts of the world.

The joint authors, however, have latterly arrived at the important conclusion that the chronological determination based upon the floral alliance, insofar as the Mine flora is concerned, is anomalous. It does not imply synchronism, because the Aso flora is not younger than the Noric and the Momonoki flora is naturally older than the Aso. Such a species as Cycadocarpidium swabii which used to be regarded as the Rhaetic indicator, occurs in a horizon as low as the basal part of the Carnic Hirabara beds.

Thus, the Carno-Noric flora present in Japan is, as discussed elsewhere, ${ }^{1)}$ rather different from the Keuper flora in the German facies. Whether this Japanese flora is a progenitor of the Rhaeto-Liassic flora of the world, or whether several of the so-called Rhaeto-Liassic floras in other places which are merely determined by the palaeobotanical ground, are older than the Rhaetic, becomes an open question that should be rechecked by cooperation among stratigrapher, palaeontologist and palaeobotanist. At any rate it is crucially important for the study on the floral development that the Mesozoic flora of the Rhaeto-Liassic aspect appeared in Japan already in the Carno-Noric Miné series and thrived in the Noric Nariwa stage.

\section{Minetrigonia, new subgenus of Trigonia.}

Diagnosis:-Shell triangularly ovate, inequilateral ; postero-dorsal area of moderate size well defined from the rest by an umbonal ridge; umbo slightly opisthogyrous; teeth of Trigonia type; adductar scars and pallial line indistinct; surface marked by lattice of radial and concentric costae.

Type:-Trigonia hegiensis Saeki.

Remark:-Yehara ${ }^{2)}$ has once grouped hegiensis in Costatae, but in its surface ornaments this is quite distinct not only from the section but from any other sections or subgenera of Trigonia so far established. In the species the costae which are branched off from the umbonal ridge cross the concentric ones on the posterior area on which account Trigonioides ${ }^{3}$ is similar to it, but they are quite different in others.

Five Triassic species of Trigonia are found to be reported with an aid of Animalium Catalogus, ${ }^{4)}$ and they are Trigonia (?) azzoralae Stoppani, ${ }^{5)}$ T. geytani v. Klipstein, ${ }^{6)} T$. seramensis Krumbeck, ${ }^{7} T$.

1) T. Kobayashi (1938), Op. cit. (Japan. Jour. Geol. Geogr. vol. 14.)

2) S. Yehara (1931), Trigoniae from Japan (Iwanami Series).

3) T. Kobayashi and K. Suzuki (1936), Non-Marine Shells of the Naktong-Wakino Series, (Japan. Jour. Geol. Geogr. vol. 13,) p. 248.

4) C. Diener (1923), Lamellibranchiata triadica, (Animalium Catalogus 19.) A. Kutassy (1931), Lamellibranchiata triadica 2, (Animalium Catalogus 51.)

5) A. Stoppani (1861), Paleontologie Lombarde III, Couches à Av. contorta, p. 58, pl. IV, fig. 1.

6) A. Bittner (1895), Lamellibranchiata der alpinen Trias, (Abh. G. R. A. XVII/1.) p. 89 , pl. X, figs. $16-18$.

7) L. Krumbeck (1923), Brachiopoden, Lamellibr. etc. aus der oberen Trias d. Insel Seran, (Palaeontogr. suppl. IV, p. 221, pl. XIV, figs. 4-8.) 
(Prosogyrotrigonia) timorensis Krumbeck ${ }^{1)}$ and T. margaritana Boehm. ${ }^{2}$ Azzoralae has a broad elliptical outline and undulating transverse ribs; geytani is subquadrate, its posterior triangular area large and tripartite by umbonal ribs, and the concentric costae are wavy at the umbonal plication. In seramensis the outline is triangular, transversely elongate and produced behind; area narrow, but fairly well defined by an umbonal ridge; concentric costae obsoleted in the posterior part. Therefore the three are obviously different from hegiensis. Prosogyrotrigonia is established out of $T$. timorensis by Krumbeck and Tancredia (Hettangia) garandi Mansuy) and T. (H.) choboensis Mansuy are referred to it. This Rhaetic subgenus can easily be distinguished from Minetrigonia by the difference of outline and surface feature.

Trigonia margaritana on the other hand probably belongs to this genus. Besides Myophoria pascoensis Steinmann,") i. e. Myophoria efr. decussata Jaworski, ${ }^{5)}$ and Myophoria suttoensis Clapp and Shimer ${ }^{6}$ appear very similar to Minetrigonia in external aspect. The hinge character is unknown in the latter species. The reference of the former to this genus is, however, more probable.")

Distribution:-Carnic; Pacific and Arctic Provinces.

\section{Trigonia (Minetrigonia) hegiensis Saeki \\ Text-figures 1-2.}

1925 Trigonia hegiensis Saeki, Jour. Geol. Soc. Tokyo, vol. 32, p. 35, pl. 12, figs. 1-3. 1925 Trigonia yeharai Saeki, ibid. p. 36, pl. 12, figs. 4-5.

Remark:-For a preliminary study it might not be imprudent to separate the transversely and longitudinally elongate forms into two distinct species, hegiensis and yeharai, but if the specific distinction is merely based on the outline of shell, it becomes unsatisfactory in such a case as the Heki shell beds where the strata are so strongly disturbed, because such a difference may be brought about by the secondary deformation. A form similar to yeharai can be artificially produced in an

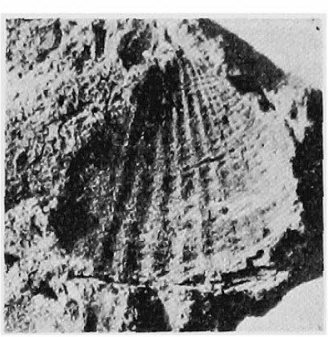

Fig. 1.

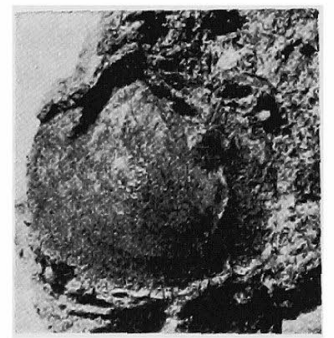

Fig. 2.

Figures 1-2. External and internal casts of a left valve of Trigonia (Minetrigonia) hegiensis Saeki from the Hirabara beds at Mugigawa, Ominé-mura, Miné-gun, Prov. Nagato. Natural size.

1) L. Krumbeck (1924), Palaeont. v. Tímor, XIII, p. 245, pl. CXCVII, figs. 19-22.

2) J. Böhm (1903), Obertriad. Fauna d. Bärensinsel, (Svenska Vet. Akad. Handl. XXXVII/3, Stockhoim), p. 43, pl. IV, figs. 31-33.

3) H. Mansuy (1912), Contribution a la Géologie du Tonkin, (Mém. Serv. géol, de l'Indo-Chine, vol. I, Fasc. 4), p. 65, pl. 12, figs. 3 a-c.

4) G. Steinmann (1929), Geologie von Perú, 57, text-figs. 56.

5) E. Jaworski (1922), Die Marine Trias in Südamerika, (N. Jahrb. f. Min. BB 47), p. 125 , pl. 5, figs. 8,8 a, text-fig. 1 .

6) J.P. Smith (1927), Upper Triassic Marine Invertebrate Faunas of North America, (U. S. Geol. Surv. Prof. Pap. 141) p. 110, pl. 105, fig. 2.

7) H. Gerth (1935), Geologie Südamerikas, (in Geologie der Erde), 2 The. S. 223. 
experiment in which a clay cast of hegiensis is subjected to lateral compression. As noticed elsewhere, ${ }^{1)}$ these two species are in fact connected by the intermediate forms in the extensive collection from Heki. Specimens from the less disturbed Miné series reveal the normal shape of hegiensis which is just intermediate between the two described by Saeki. Therefore yeharai should be synonymized with hegiensis.

Occurrence:-The Heki shell beds of Heki, Prov. Tamba; Hirabara beds of the Miné series in Prov. Nagato; Oxytoma bed of the Sakawa series in the Sakawa basin, Prov. Tosa.

1) T. Kobayashi (1935), Contributions to the Mesozoic Faunas of Japan, (Jour. Geol. Soc. Japan vol. 42), p. 193. 